\title{
IDENTIFIKASI NEMATODA USUS SOIL TRANSMITTED HELMINTH PADA ANAK-ANAK DI KECAMATAN BARANTI KABUPATEN SIDENRENG RAPPANG
}

\author{
Dian Islamiati, Mujahidah Basarang, Muh. Rifo Rianto, Anita, Tuty Widyanti \\ Program Studi D3 Teknologi Laboratorium Medis, Politeknik Kesehatan Muhammadiyah Makassar \\ E-mail: dianislamia@gmail.com
}

\begin{abstract}
Soil Transmitted Helminths or intestinal nematodes are a group of intestinal worm parasites that require moist and moist soil media for their development. The soil-transmitted helminth (STH) groups are roundworms (Ascaris lumbricoides), whipworms (Trichuris trichiura), hookworms (Necator americanus and Ancylostoma duodenale) and thread worms (Strongyloides stercoralis). and improper placement of waste water reservoirs results in contamination of the soil which is a breeding ground for intestinal nematodes. This study aims to identify soil-transmitted helminths in the feces of children in Baranti District, Sidenreng Rappang Regency. This type of research is laboratory observation. A total of 10 stool samples using the sedimentation method (centrifugation). Based on the results of the research that has been done, it was found that 2 samples were positive for worm eggs. Based on the results of the study, it can be concluded that soil-transmitted helminths were found in children with Ascaris lumbricoides and Trichuris trichiura eggs.
\end{abstract}

Keywords: Soil Transmitted Helminth (STH), Sedimentation method

\begin{abstract}
Abstrak
Soil Transmitted Helminth atau nematoda usus adalah kelompok parasit cacing usus yang memerlukan media tanah yang basah dan lembab untuk perkembangannya. Kelompok soil transmitted helminth (STH) yakni cacing gelang (Ascaris lumbricoides), cacing cambuk (Trichuris trichiura), cacing tambang (Necator americanus dan Ancylostoma duodenale) dan cacing benang (Strongyloides stercoralis). Dilihat dari kondisi lingkungan Kecamatan Baranti terdapat penggunanaan jamban yang tidak layak dan peletakan penampungan air limbah sembarangan mengakibatkan kontaminasi pada tanah yang menjadi tempat berkembangnya nematoda usus. Pengabdian ini bertujuan untuk mengidentifikasi soil transmitted helminth pada feses anak-anak di Kecamatan Baranti Kabupaten Sidenreng Rappang. Jenis pengabdian ini adalah observasi laboratorik. Sebanyak 10 sampel feses dengan menggunakan metode sedimentasi (sentrifugasi). Berdasarkan hasil pengabdian yang telah dilakukakan ditemukan 2 sampel yang positif mengandung telur cacing. Berdasarkan hasil pengabdian dapat disimpulkan bahwa ditemukan soil transmitted helminth pada anak-anak dengan jenis telur cacing Ascaris lumbricoides dan Trichuris trichiura.
\end{abstract}

Kata kunci: Soil Transmitted Helminth (STH), Metode sedimentasi 


\section{PENDAHULUAN}

Helminthiasis atau penyakit kecacingan merupakan infeksi cacing dari golongan nematoda usus. Nematoda usus memiliki 5 spesies yang penularannya melalui tanah atau dikenal dengan cacing soil transmitted helminth (STH) (Supali, et al. 2008). Cacing yang tergolong STH yaitu Ascaris lumbricoides, Trichuris trichiura, Necator americanus, Ancylostoma duodenale dan Strongyloides stercoralis.

Tanah merupakan media pertumbuhan telur untuk menjadi infektif bagi manusia, sifat tanah mempunyai pengaruh terhadap perkembangan telur dan daya tahan hidup dari larva cacing (Supali, et al, 2008).

Menurut WHO tahun 2015 lebih dari 1,5 miliar orang atau 24\% populasi dunia terinfeksi soil transmitted helminth. Kasus infeksi Soil Transmitted Helminth terjadi karena tertelannya telur atau larva cacing yang ada ditanah melalui kulit (WHO, 2016). Prevalensi kecacingan dilihat dari wilayah-wilayah tertentu dengan kondisi sanitasi yang buruk mencapai 80\% (Anis dan Rosmini, 2017).

Beberapa hasil menunjukkan kecacingan lebih banyak menyerang pada anak-anak. Lebih dari 270 juta anak usia pra sekolah dan 600 juta anak usia sekolah di dunia tinggal di daerah yang memiliki angka penyebaran infeksi soil transmitted helminth yang tinggi (Noviastuti, 2015)

Prevalensi tertinggi ditemukan pada anak golongan usia sekolah dasar yaitu usia 7-12 tahun karena berhubungan dengan kebiasaan anak-anak yang sering bermain dan terkontaminasi langsung dengan telur cacing yang berasal dari tanah (Junus dan Marlina, 2012).

Anak-anak sangat rawan akan infeksi karena kurangnya memperhatikan kebersihan pada diri sendiri, hygiene sangat dipengaruhi oleh lingkungan, arahan orang tua, lingkungan keluarga yang mendidiknya dan sanitasi tempat tinggalnya (Junus dan Marlina, 2012).

Kabupatan Sidenreng Rappang merupakan kabupaten yang strategi sanitasinya kuran baik dikarenakan pengaruh aktivitas masyarakat. Terdapat permasalahan yang paling mendesak yaitu terdapat 7,3\% kasus buang air besar sembarangan dan terdapat 3,02\% jamban yang tidak layak di perdesaan. Terdapat 4 kecamatan yang berada di area beresiko tinggi, salah satunya adalah Kecamatan Baranti (Masse, 2017).

Kecamatan Baranti memiliki 4 desa dan 5 kelurahan. Dari beberapa lokasi masih ditemukan 29\% per KK kasus buang air besar sembarangan (BABS) masyarakat setempat dan masih ada yang menggunakan closet cemplong (cubluk). Dari data strategi sanitasi kota pada wilayah Baranti prasarana air limbah dan pengelolaan lumpur tinja belum diadakan sehingga limbah rumah tangga langsung terbuang ke tanah (Masse, 2017).

Masyarakat di Baranti terdapat 55,4\% penggunaan jamban yang tidak layak dan juga peletakan penampungan air limbah di sembarang tempat sehingga dapat mengakibatkan kontaminasi pada air, tanah, atau menjadi sumber infeksi bagi kesehatan seperti tifoid, kolera, penyakit cacing dan disentri (Rachim dan Saleh. 2014).

Kondisi sanitasi dasar yang tidak memenuhi syarat kesehatan merupakan kondisi yang kondusif untuk berkembangnya penyakit kecacingan. Hal inilah yang mendorong dilakukannya pengabdian ini untuk mengetahui infeksi nematoda usus Soil Transmitted Helminth pada anakanak yang tinggal di Kecamatan Baranti Kabupaten Sidenreng Rappang.

\section{METODE}

Alat yang digunakan dalam pengabdian ini adalah mikroskop, objek glass, deck glass, lidi, pipet tetes, tabung reaksi, sentrifuge, rak tabung, pengaduk, beaker glass, dan timbangan elektrik. Bahan yang digunakan dalam pengabdian ini adalah feses, aquadest, larutan eosin $2 \%$, larutan lugol atau larutan garam fisiologis ( $\mathrm{NaCl} 90 \%)$.

Pengumpulan sampel didasarkan pada kriteria yaitu anak-anak yang tidak menggunakan sendal, tidak merawat kebersihan kuku, tangan dan kaki, dan tidak mengkonsumsi obat cacing. Pengumpulan sampel melibatkan kerjasama dengan orang tua. Pot sampel diberikan kepada orang tua anak-anak di Kecamatan Baranti. Feses setiap anak dimasukkan ke dalam pot sampel 
yang telah dibagikan. Sampel yang sudah terkumpul akan segera di periksa dengan menggunakan metode sedimentasi.

Prosedur kerja yang digunakan dalam pengabdian ini adalah metode sedimentasi. Ditimbang feses sebanyak $2 \mathrm{~g}$ lalu dicampur dengan akuades sampai tanda ukuran $100 \mathrm{ml}$ pada beaker glass lalu dihomogenkan dengan bantuan batang pengaduk. Larutan feses yang telah dicampur tadi dipipet kedalam tabung reaksi hingga permukaannya, kemudian disentrifuge dengan kecepatan $3000 \mathrm{rpm}$ selama 5 menit, lalu larutan yang telah disentrifuge dibuang sebanyak dua per tiga dari permukaan tabung, ditambahkan aquadest dan diaduk pelan-pelan, prosedur diulangi hingga larutan dipermukaan tabung menjadi jernih. Jika supernatannya telah jernih maka endapan di dasar tabung di ambil dengan menggunakan pipet tetes lalu diletakkan di atas objek glass yang bersih dan kering lalu di tutup dengan deck glass. Kemudian preparat di periksa dibawah mikroskop dengan pembesaran 10x dan 40x.

Interpretasi Hasil: Positif / + = Ditemukan telur cacing

$$
\text { Negatif } / \text { - = Tidak ditemukan telur cacing }
$$

\section{HASIL DAN PEMBAHASAN}

Pengabdian yang dilakukan pada tanggal 3-4 Mei 2021 bertujuan untuk mengidentifikasi nematoda usus Soil Transmitted Helmints pada anak-anak di Kecamatan Baranti Kabupaten Sidenreng Rappang. 10 sampel yang dikumpulkan sibawa ke laboratorium Parasitologi Politeknik Kesehatan Muhammadiyah Makassar untuk diperiksa menggunakan metode sedimentasi. Adapun hasil pemeriksaan yang didapatkan adalah sebagai berikut:

Tabel 1. Hasil pemeriksaan telur cacing soil transmitted helminth (STH) pada anak-anak di Kecamatan Baranti Kabupaten Sidenreng Rappang

\begin{tabular}{cccc}
\hline $\begin{array}{c}\text { Kode } \\
\text { Sampel }\end{array}$ & $\begin{array}{c}\text { Umur } \\
(\text { Th) }\end{array}$ & Hasil & Keterangan \\
\hline A1 & 7 & Negatif (-) & - \\
A2 & 7 & Negatif (-) & - \\
A3 & 8 & Negatif (-) & - \\
A4 & 9 & Negatif (-) & - \\
A5 & 10 & Negatif $(-)$ & - \\
A6 & 11 & Negatif (-) & - \\
A7 & 12 & Positif $(+)$ & Telur cacing Ascaris \\
& & & $\begin{array}{l}\text { lumbricoides dan } \\
\text { Trichuris trichiura }\end{array}$ \\
A8 & 10 & Negatif (-) & - \\
A9 & 8 & Negatif $(-)$ & - \\
A10 & 10 & Positif $(+)$ & Telur cacing Trichuris \\
& & & trichiura \\
\hline
\end{tabular}

Sampel dikumpulkan dari anak-anak yang berumur 7-12 tahun. Sampel A7 merupakan anak yang berusia 12 tahun. Dari hasil pengamatan mikroskopis sampel ini positif dan mengandung 2 jenis telur cacing soil transmitted helminth yaitu Ascaris lumbricoides dan Trichuris trichiura. Dari observasi yang telah dilakukan bahwa yang menjadi latar belakang anak ini dapat terjangkit helminthiasis dikarenakan anak ini tinggal ditempat dengan kondisi lingkungan yang kurang baik. Yaitu penggunaan jamban yang tidak layak dan peletakan penampungan air limbah tinja rumahnya sembarangan. Dampak dari adanya cacing ini sudah terlihat jelas dimna anak ini 
mengalami gatal-gatal pada bagian tangan dan kakinya, susah mengingat sesuatu, badan terlihat kurus, dan tidak dapat membaca.
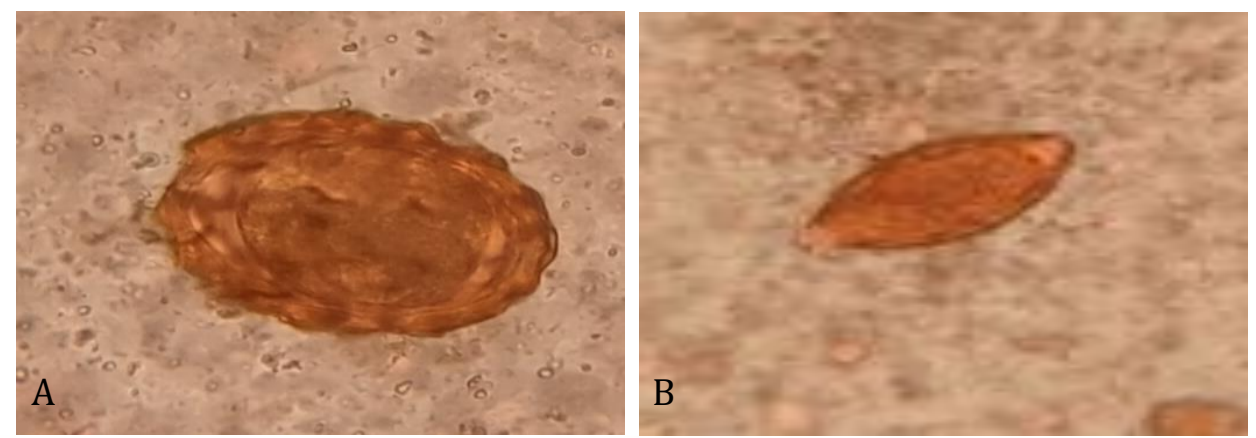

Gambar 1. Telur cacing pada sampel A7, A. Ascaris lumbricoides,

\section{B. Trichuris trichiura}

Sedangkan sampel A10 merupakan anak yang berusia 9 tahun. Dari hasil pengamatan mikroskopis sampel ini positif mengandung jenis telur cacing Ascaris lumbricoides. Dilihat dari observasi yang telah dilakukan bahwa yang menjadi latar belakang anak ini dapat terjangkit helminthiasis dikarenakan kondisi dapur dirumahnya hanya beralaskan tanah dan peletakan penampungan air limbah tinja yang terletak dibelakang rumah sehingga dapat terkontaminasi pada tanah yang ada di dapur karena limbah langsung terbuang ke tanah, dan anak ini juga tidak suka menggunakan alas kaki dirumahnya.

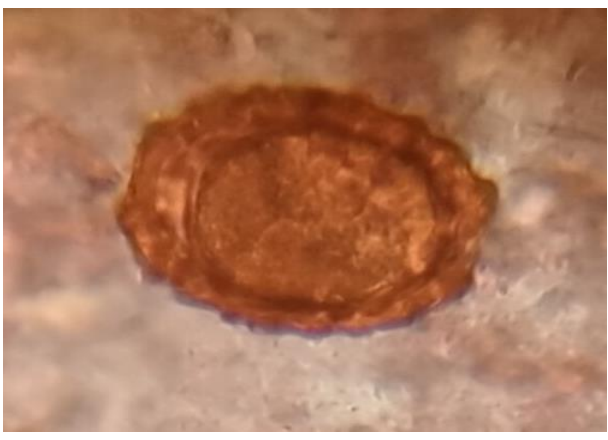

Gambar 1. Telur cacing Ascaris lumbricoides pada sampel A10

Adapun faktor-faktor yang dipengaruhi ditemukannya anak-anak yang terinfeksi soil transmitted helmint (STH) yaitu kondisi eksternal lingkungan seperti tanah, penggunaan jamban yang tidak layak dan juga peletakan penampungan air limbah yang dapat mengkontaminasi tanah. Pola hidup berada di lingkungan yang kurang bersih, sehingga dapat terkontaminasi atau menyebar melalui makanan dan minuman mereka, sehingga anak-anak tersebut terinfeksi kecacingan (Irianto, 2009)

Penyakit yang dapat ditimbulkan dari jenis cacing ini yaitu askariasis dan trikuriasis yang menimbulkan gatal-gatal pada seluruh bagian tubuh, kekurangan nafsu makan, sehingga kesehatan fisik dan kecerdasan pada anak-anak dapat terganggu. Apabila infeksi ini tidak ditangani dengan cepat, maka dapat merusak usus serta menurunkan sistem kekebalan pada tubuh.

Pada dasarnya infeksi kecacingan dapat dicegah dan disembuhkan dengan cara menjaga kebersihan diri sendiri, meminum obat cacing secara teratur ( 6 bulan sekali), menjaga pola hidup sehat dan bersih serta memperhatikan kebersihan lingkungan sekitar. Karena dengan memperhatikan kebersihan adalah cara untuk menghalangi penyakit kecacingan. 


\section{KESIMPULAN}

Berdasarkan pengabdian yang elah dilakukan dapat disimpulkan bahwa dari 10 sampel feses anak-anak di Kecamatan Baranti Kabupaten Sidenreng Rappang menunjukkan 2 sampel yang hasilnya positif yaitu dari sampel terdapat nematode usus soil transmitted helminth dengan jenis telur cacing Ascaris lumbricoides dan Trichuris trichiura.

\section{DAFTAR PUSTAKA}

Gandahusada. 2008. Parasitologi Kedokteran. Balai Penerbit Fakultas Kedokteran UI. Jakarta.

Irianto, K. 2009. Parasitologi Berbagai Penyakit yang Mempengaruhi Kesehatan Manusia. C.V, Yrama Widya. Bandung.

Junus, W \& Marlina, L. 2012. Hubungan Pendidikan Formal, Pengetahuan Ibu dan Sosial Ekonomi Terhadap Infeksi Soil Transmitted Helminths pada Anak Sekolah Dasar di Kecamatan Seluma Timur Kabupaten Seluma Bengkulu. Jurnal Ekologi Keseatan,11(1),33-39.

Masse, R. 2017. Strategi Sanitasi Kota Kabupaten Sidenreng Rappang Tahun 2018-2022, (online), (http://portal.nawasis.info/public/dokumensskfinal_list.php?=(idprop equals 73, diunduh 3 oktober 2020).

Muslim, H.M. 2015, Buku Ajar Helmintologi. Akademi Analis Kesehatan Borneo Lestari. Banjarbaru.

Natadisastra, D \& Agoes, R. 2009. Parasitologi Kedokteran Ditinjau dari Organ Tubuh Yang Diserang. ECG. Jakarta.

Noviastuti, A, R. 2015. Infeksi Soil Transmitted Helmint. Majority,4(8),107-116.

Peraturan Menteri Kesehatan, Nomor 15 Tahun 2017. Tentang Penanggulangan Kecacingan. Jakarta.

Prianto, J. 2010. Atlas Parasitologi Kedokteran. PT Gramedia Pustaka Utama. Jakarta.

Rachim, H. L \& Saleh, M. 2014. Hubungan Kondisi Sanitasi Lingkungan dengan Kejadian Diare pada Anak Balita di Wilayah Kerja Puskesmas Baranti Kabupaten Sidrap Tahun 2013. Jurnal Kesehatan, VII (1), 221-233.

Soedarto, 2011. Buku Ajar Parasitologi Kedokteran. Sagung Seto. Jakarta.

Supali, T. Margono, S. S. \& Abidin, S. A. N. 2008. Buku Ajar Parasitologi Kedokteran. Edisi Ke 4. Balai Penerbit Fakultas Kedokteran Universitas Indonesia. Jakarta.

WHO, 2016. Soil Transmitted Helminths, (online), (www.who.int/intestinal_worms/en, diunduh 15 April 2021).

Widoyono, R. 2011. Penyakit Tropis Epidemiologi, Penularan, Pencegahan dan Pemberantasan. Erlangga. Jakarta. 